\title{
A rare case of spontaneous tracheal perforation
}

\author{
Sebastian Thomas Lugg, ${ }^{1,2}$ Frances Grudzinska, ${ }^{1,2}$ Maninder Singh Kalkat, ${ }^{1}$ \\ Benjamin Sutton ${ }^{1}$
}

${ }^{1}$ Queen Elizabeth Hospital Birmingham, University Hospitals Birmingham NHS Foundation Trust, Birmingham, UK

${ }^{2}$ Institute of Inflammation and Ageing, Centre for Translational Inflammation Research, University of Birmingham, Birmingham, UK

\section{Correspondence to} Dr Sebastian Thomas Lugg, Sebastian.Lugg@nhs.net

Accepted 9 June 2017

\section{(1) \\ CrossMark}

To cite: Lugg ST Grudzinska F, Kalkat MS, et al. BMJ Case Rep Published Online First: [please include Day Month Year]. doi:10.1136/bcr-2017220731

\section{DESCRIPTION}

A 25-year-old man presented with spontaneous surgical emphysema resulting in swelling of his upper torso, neck and face. He had an allogeneic bone marrow transplant (BMT) 1 year earlier for acute myeloid leukaemia, complicated by severe refractory chronic graft-versus-host disease (GVHD). The CT thorax demonstrated a tracheal defect causing pneumomediastinum, marked surgical emphysema and features of atypical pulmonary infection (figure 1). The flexible bronchoscopy confirmed the presence of two anterior perforations in the cervical trachea (figure 2). No samples were taken for microscopy as the patient desaturated during bronchoscopy and the procedure was abandoned.

Empirical antimicrobial and antifungal treatment were commenced. Definitive surgical repair (eg, muscle flap $)^{1}$ was not considered as the patient's general condition was very poor, the trachea was universally diseased and the defects were large in size. In addition, these defects were not compromising ventilation nor was there worsening of the surgical emphysema. Insertion of a stent risked widening the defects and aggravating ongoing infection, therefore he was managed conservatively. His general condition, however, deteriorated throughout the admission and he died due to steroid refractory GVHD secondary to the BMT.

Tracheal perforation is rare and usually occurs as a result of intubation, blunt trauma, foreign body inhalation or local tumour invasion. Spontaneous tracheal perforation is rarer still. There are no reported cases of GVHD causing tracheal perforation; however co-existing Aspergillus infection is found frequently in BMT patients with airway disease, ${ }^{2}$ and has also been associated with tracheal perforation and fistula formation in immunocompromised patients. ${ }^{13}$

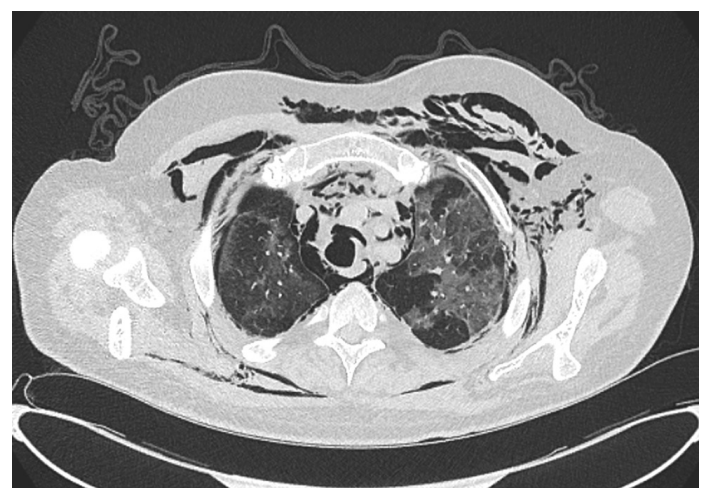

Figure $1 \mathrm{CT}$ thorax shows a defect in the anterior wall of the trachea causing pneumomediastinum and marked surgical emphysema. The lungs show patchy areas of ground-glass opacification suspicious of an atypical infection.

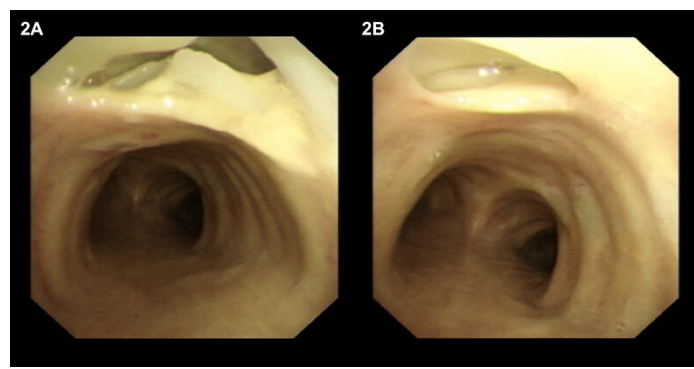

Figure 2 Bronchoscopy reveals two perforations in the anterior tracheal wall essentially midline. (A) The largest is at the $12 o^{\prime}$ clock position, extending horizontally to involve about a $30^{\circ}$ arc and is approximately $15-20 \mathrm{~mm}$ across by $10 \mathrm{~mm}$ superior-inferior. (B) The smaller, more inferior hole is circular, approximately $5 \mathrm{~mm}$ in diameter and $10 \mathrm{~mm}$ below slough is visible.

\section{Learning points}

- Tracheal perforation is a rare event and usually secondary to other causes such as intubation, blunt trauma, foreign body inhalation or local tumour invasion.

- The management of tracheal perforation remains primarily surgical repair; a stent is used either in the palliative setting or as a bridge to definitive surgical procedure.

- Aspergillus infection is associated with tracheal perforation in immunocompromised patients; additional antifungal therapy should always be considered in these individuals.

Contributors STL drafted the final manuscript and carried out the literature review. FG carried out the data collection and assisted in manuscript preparation. MSK and BS conceived the study and have critically revised the final manuscript. All authors read and approved the final manuscript.

Competing interests None declared.

Patient consent Obtained.

Provenance and peer review Not commissioned; externally peer reviewed.

(c) BMJ Publishing Group Ltd (unless otherwise stated in the text of the article) 2017. All rights reserved. No commercial use is permitted unless otherwise expressly granted.

\section{REFERENCES}

1 Gonzalez M, Ma Tooh M, Krueger T, et al. Repair of tracheal aspergillosis perforation causing tension pneumothorax. Ann Thorac Surg 2013;96:2256-8.

2 Yokoi T, Hirabayashi N, Ito M, et al. Broncho-bronchiolitis obliterans as a complication of bone marrow transplantation: a clinicopathological study of eight autopsy cases. Nagoya BMT Group. Virchows Arch 1997;431:275-82.

3 Argento AC, Wolfe CR, Wahidi MM, et al. Bronchomediastinal fistula caused by endobronchial aspergilloma. Ann Am Thorac Soc 2015;12:91-5. 
Copyright 2017 BMJ Publishing Group. All rights reserved. For permission to reuse any of this content visit http://group.bmj.com/group/rights-licensing/permissions.

BMJ Case Report Fellows may re-use this article for personal use and teaching without any further permission.

Become a Fellow of BMJ Case Reports today and you can:

- Submit as many cases as you like

- Enjoy fast sympathetic peer review and rapid publication of accepted articles

Access all the published articles

- Re-use any of the published material for personal use and teaching without further permission

For information on Institutional Fellowships contact consortiasales@bmjgroup.com

Visit casereports.bmj.com for more articles like this and to become a Fellow 